\title{
Who's that girl? A singular Tropiduchidae planthopper from the Eocene Baltic amber (Hemiptera: Fulgoromorpha)
}

\author{
Jacek Szwedo and Adam Stroiński
}

\begin{abstract}
A new tribe of Tropiduchidae planthoppers is described from the Baltic amberGedanotropidini trib. nov., with a new genus and species Gedanotropis sontagae gen. et sp. nov. A key to the tribes and genera of Tropiduchidae from the Eocene Baltic amber is presented. Use of FT-IR spectrophotometry for confirmation of provenance of museum material and its documentation is proposed. The ecoevolutionary consequences of particular morphological characters of the new taxa and 'flatoidinisation syndrome' are introduced and discussed.
\end{abstract}

Jacek Szwedo. Laboratory of Evolutionary Entomology, Department of Invertebrate Zoology and Parasitology, Faculty of Biology, University of Gdańsk, 59, Wita Stwosza St., PL80-308 Gdańsk, Poland. jacek.szwedo@biol.ug.edu.pl Adam Stroiński. Museum and Institute of Zoology, Polish Academy of Sciences, 64, Wilcza St., PL00-679 Warszawa, Poland. adam@miiz.waw.pl

Keywords: new tribe; new genus; new species; 'flatoidinisation syndrome'; Baltic amber

Submission: 19 May 2017 Acceptance: 21 November 2017

\section{INTRODUCTION}

The Tropiduchidae Stål, 1854, the family of planthoppers (Fulgoromorpha) comprising more than 180 genera with over 650 species (Bourgoin, 2017 ) is currently a highly diversified group morphologically, ecologically and taxonomically. Their size ranges from 5 to $13 \mathrm{~mm}$ in length (O'Brien and Wilson, 1985; O'Brien, 2002). Recent Tropiduchidae inhabit a wide range of habitats across the globe, from warm and wet tropical and subtropical forests, to dry and semi-dry deserts and savannahs (Fennah, 1982; Gnezdilov, 2012b; Bourgoin 2017). Some species are known as crop pests, but most species feed on shrubs and trees (Fennah, 1982; Wilson et al., 1994; O'Brien, 2002) and particularly Arecales and Gentianales that represent about $25 \%$ of the records (Bourgoin, 2017).

The higher classification of the family was for the first time developed by Melichar (1914). Later,

http://zoobank.org/580BB6E1-5341-4459-BF12-3EBC7CC26EEE

Szwedo, Jacek and Stroiński, Adam. 2017. Who's that girl? A singular Tropiduchidae planthopper from the Eocene Baltic amber (Hemiptera: Fulgoromorpha). Palaeontologia Electronica 20.3.60A: 1-20. https://doi.org/10.26879/784 palaeo-electronica.org/content/2017/2079-tropiduchid-from-baltic-amber

Copyright: December 2017 Palaeontological Association.

This is an open access article distributed under the terms of Attribution-NonCommercial-ShareAlike 4.0 International (CC BY-NC-SA 4.0), which permits users to copy and redistribute the material in any medium or format, provided it is not used for commercial purposes and the original author and source are credited, with indications if any changes are made. creativecommons.org/licenses/by-nc-sa/4.0/ 
Fennah (1982) proposed a new classification system. The most recent proposal (Gnezdilov, 2013b) divides the family into two subfamilies. During the last few years both fossil and recent Tropiduchidae attracted attention of researchers (Szwedo, 2000; Wang R.R. and Liang, 2006, 2007, 2008, 2011; Shcherbakov, 2006; Gnezdilov, 2007, 2012a, 2013b; Fletcher, 2008; Liang and Wang R.R., 2008a, 2008b; Wang R.R. et al., 2009, 2012a, 2012b, 2013a, 2013b, 2014, 2017; Stroiński and Gnezdilov, 2009; Szwedo and Stroiński, 2010, 2013; Gnezdilov, 2012a, 2012b, 2013b; Chang and Chen, 2014a, 2014b; Constant, 2015; Gnezdilov and Bourgoin, 2015; Junkiert and Walczak, 2015; Stroiński et al., 2015; Wang M.L. et al., 2015; Gnezdilov et al., 2016; Junkiert et al., 2017). As a result of these, the total number of tribes recognised currently raised to 24 (some of them subdivided into subtribes), including four extinct ones (Appendix 1). Finally, after a number of taxonomic changes, shifting of several groups to Tropiduchidae from other families, together with description of extinct tribes, the definition of the family became rather vague (Bartlett et al., 2014, Gnezdilov et al., 2016). As a result we are now without a single autapomorphic character allowing a clear and simple definition of family, which questions its monophyly in current status and content. The phylogenetic investigations on the Tropiduchidae are at their infancy, with the only phylogenetic work done for the tribe Tropiduchini at the moment (Wang et al., 2017).

The oldest fossil record of the family is that from the Turonian, the Upper Cretaceous (Szwedo, 2009; Nicholson et al., 2015), but the formally described taxa comes from the Eocene Baltic amber-extinct tribes Jantaritambini, Austrini and Patollini, and recent tribe Elicini (Szwedo and Stroiński, 1999, 2010, 2013; Szwedo, 2000)—and from the Lutetian (middle Eocene) deposits of the Green River Formation with extinct Emilianini (Shcherbakov, 2006). The fossil described below cannot be placed in any of the currently recognised tribes of Tropiduchidae, and represents another extinct and peculiar group of these planthoppers. This fossil still brings more questions on morphological characters and their disparity within the taxa attributed to the Tropiduchidae-classification, relationships and evolutionary history of the family.

\section{MATERIAL AND METHODS}

Baltic amber has been a subject of longstanding debates about its botanical origin, formation and age, about its accumulation and origin of its deposits. The biggest concentration of amber in the deposit, in the Gulf of Gdańsk (Sambian Peninsula to Chłapowo), is definitively secondary one; the other deposits, i.e., Górka Lubartowska amber (Lublin Region, Poland), Ukrainian amber (deposits near Klesov, Rovno and Zhitomir; Bogdasarov, 2010; Perkovsky et al., 2010), Bitterfeld amber (Rascher et al., 2008; Wolfe et al., 2016) are variously aged and secondary as well. Absolute dating analyses of glauconites from Sambia Peninsula showed that the "blue earth" formation (amber bearing Prussian Formation) is allocated to the Middle Eocene (Lutetian: $44.1 \pm 1.1 \mathrm{Ma}$ ) and is thus significantly older than previously assumed (Wappler, 2003, 2005). Limnic sediments of Eckfeld Maar, aged $44.3 \pm 0.4 \mathrm{Ma}$, correlate with $\mathrm{K}-\mathrm{Ar}$ radiometric data from the Sambia Peninsula and contain insect genera known only from Baltic amber (Wappler 2005). For details and overview of discussions see supplementary information in Szwedo and Drohojowska (2016) and Kosmowska-Ceranowicz (2017).

The studied specimen is a piece of transparent amber, polished in form of irregular plate; weight $12.66 \mathrm{~g}$, size $50 \times 32 \times 11 \mathrm{~mm}$. Reference IR curves of the piece numbered as MAI UG 508762 IR are deposited in MAI UG (Museum of Amber Inclusions, University of Gdańsk, Gdańsk, Poland) (Figure 1.1-2). Inclusion of Gedanotropis sontagae gen. et sp. nov. (Figure 1.3-4)—dorsal portion is partly covered with milky veil and some bubbles of gas obscuring the specimen; right tegmen is partly damaged; left tegmen with apical portion missing; ventral surface of the inclusion is partly obscured by milky veil, internal cracks and bubbles of gas. Syninclusions are two specimens of Collembola: Symphypleona: Sminthuridae (one partly damaged) and small particles of detritus.

Amber was cut, grinded and polished prior the study. Observations and documentation were made using stereoscopic microscope Olympus SZH10, Olympus DSX100 free angle wide zoom microscope, and stereoscopic microscope Leica M205A. The photographs were taken using Olympus C-5060 digital camera under QuickPHOTO 2.0 software attached to Olympus SZH10 microscope, Olympus DSX100 microscope, and with Leica DM6000 attached to Leica M205A microscope under control the LAS Montage multifocus. Photographs were readjusted using Adobe Photoshop Elements 6.0 software. Drawings were made with camera lucida attached to Olympus SZH10 and Leica M2015A microscopes. 

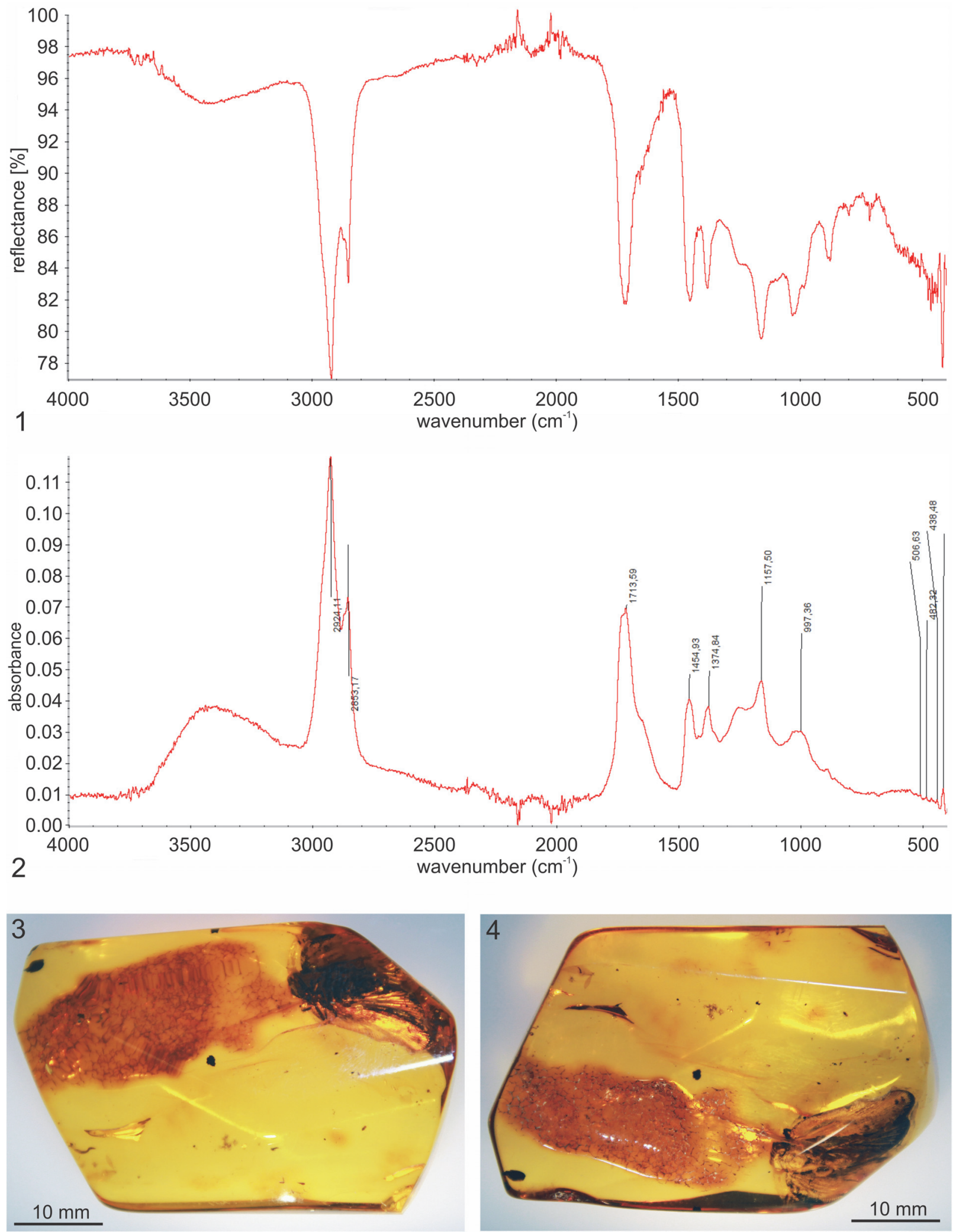

FIGURE 1. 1-2, FT-IR spectra of the amber specimen MAI UG 508762: FT-IR spectrum (1) and ATR corrected FT-IR spectrum with baseline corrected (2). 3-4, Piece of amber MAI UG 508762 with inclusion of Gedanotropis sontagae gen. et sp. nov., lower (3) and upper (4) sides. 
The number of rostrum segments in Fulgoromorpha varies from 3 to 5 (Brożek et al., 2006); thus, for numbering of rostrum segments we propose the following nomenclature, counting from a base: basal segments 1-3 (there can be one, two or three segments basad of subapical one); subapical segment and apical segment.

Venation of wings is based on Bourgoin et al. (2015), with following abbreviations:

$\mathrm{PC}+\mathrm{CA}$, precosta + costa anterior; CP, costa posterior; ScP, subcosta posterior; $\mathrm{R}$, radius; $\mathrm{ScP}+\mathrm{R}(+\mathrm{MA})$, common portion of subcosta posterior, radius and media anterior; MA, media anterior is always fused with vein $R$ (apomorphy of the Hemiptera), so we use here abbreviated notion $\mathrm{ScP}+\mathrm{R}$ denoting this common stem (Bourgoin et al., 2015); ScP+RA, common portion of subcostal posterior and radius anterior; RA, radius anterior; $\mathrm{RP}$, radius posterior (with MA fused); $\mathrm{MP}$, media posterior; CuA, cubitus anterior; CuP, cubitus posterior; Pcu, postcubitus; and $A_{1}$, first anal vein. The naming and numbering of cells and areas of the tegmina is also based on Bourgoin et al. (2015).

FT-IR spectrum (Figure 1.1-2) was obtained in the Laboratory of the International Amber Association, Gdańsk, Poland with Nicolet iS10 Spectrometer with an ATR (Attenuated Total Reflectance; diamond crystal) accessory. Spectra were registered with resolution $4 \mathrm{~cm}^{-1}$, baseline correction and advanced ATR correction were applied. Reference curve numbers in the collection archives are stored as registration number of the specimen, with suffix 'IR'. This procedure must be regarded now as obligatory for the museum material, especially holotypes, for various reasons. First, there are numerous fakes offered in the market (Grimaldi et al., 1994), and the type of amber or fossil resin must be examined to receive confirmation of its kind. The fakes could be made in various ways, e.g., by autoclaving the more recent resins rich in inclusions, such as Colombian copal. Second, Baltic amber and other resins are altered due to process of autoclaving (treatment with heat and pressure), which sometimes gives the benefits for investigations removing the "milky veil" often present on the inclusions, on the other hand it could heavily alter the inclusion, its dimensions or shape of important taxonomic features (Szwedo and Sontag, 2009). Such treatment is to be identified with use of FT-IR spectrum (Wang Y. et al., 2014; Kosmowska-Ceranowicz, 2015). The knowledge about the treatment is important for curatorial purposes, as treated amber could deteriorate much faster than the raw, polished-only one (Bisulca et al., 2012).

\section{SYSTEMATIC PALAEONTOLOGY}

Class INSECTA Linnaeus, 1758

Order HEMIPTERA Linnaeus, 1758

Family TROPIDUCHIDAE Stål, 1866

Subfamily ELICINAE Melichar, 1915

Tribe GEDANOTROPIDINI trib. nov.

zoobank.org/2E6C6A9A-CBDD-434B-85C5-8E87146EE45E

Type genus. Gedanotropis gen. nov., designated herein.

Etymology. The generic name is derived from the Ancient Greek stem 'trop-' (nominativus), 'tropid-' (genetivus), of the word 'тро́тıб; тро́тıбоs' - trópis, trópidos (keel of the ship), i.e. according with ICZN (2000) Article 29.3.1, the stem 'tropid-' must be used for creation family-group taxon name.

Diagnosis. Vertex, disc of pronotum and disc of mesonotum in ascending, stepwise planes. Tegmen macropterous with full venation developed; costal area present, with transverse veinlets; nodal line absent. Gonoplac rounded, its median, membranous part without denticles.

Description. Frons with median carina; clypeus with median carina and without lateral carinae. Antennal plate organs present in apical and dorsal portion to half of pedicel length. Mesonotum without median carina, lateral carinae converging anteriad. Vertex, disc of pronotum and disc of mesonotum in ascending, stepwise planes. Mesonotum elevated, with intercarinal median disc flattened. Tegmen wide, costal area with transverse veinlets; anterior margin strongly curved at base, clavus long, with apex exceeding $3 / 4$ of tegmen length; tornus absent. Stem ScP+R and stem $\mathrm{RP}(+\mathrm{MA})$ leaving basal cell at a single point; stem MP short, branch $\mathrm{MP}_{1+2}$ forked basad of branch $\mathrm{MP}_{3+4}$ forking. Clavus with transverse veinlets. Metatibia with lateral spines. Gonoplac rounded; posterior margin without teeth; membranous part medially without denticles (Figures 2-4).

Remarks. The tribes of Tropiduchidae, as understood nowadays, are defined by combination of various characters. Vertex, disc of pronotum and mesonotum of Tropiduchidae are placed in a single plane, making the stepwise planes in the newly described tribe exceptional and apomorphic. Representatives of the family vary in length and structure of tegmina, with costal area present or absent, with or without transverse veinlets. In 'typical' Tropiduchinae, the nodal line is present and developed variously, however in Elicinae the nodal line 


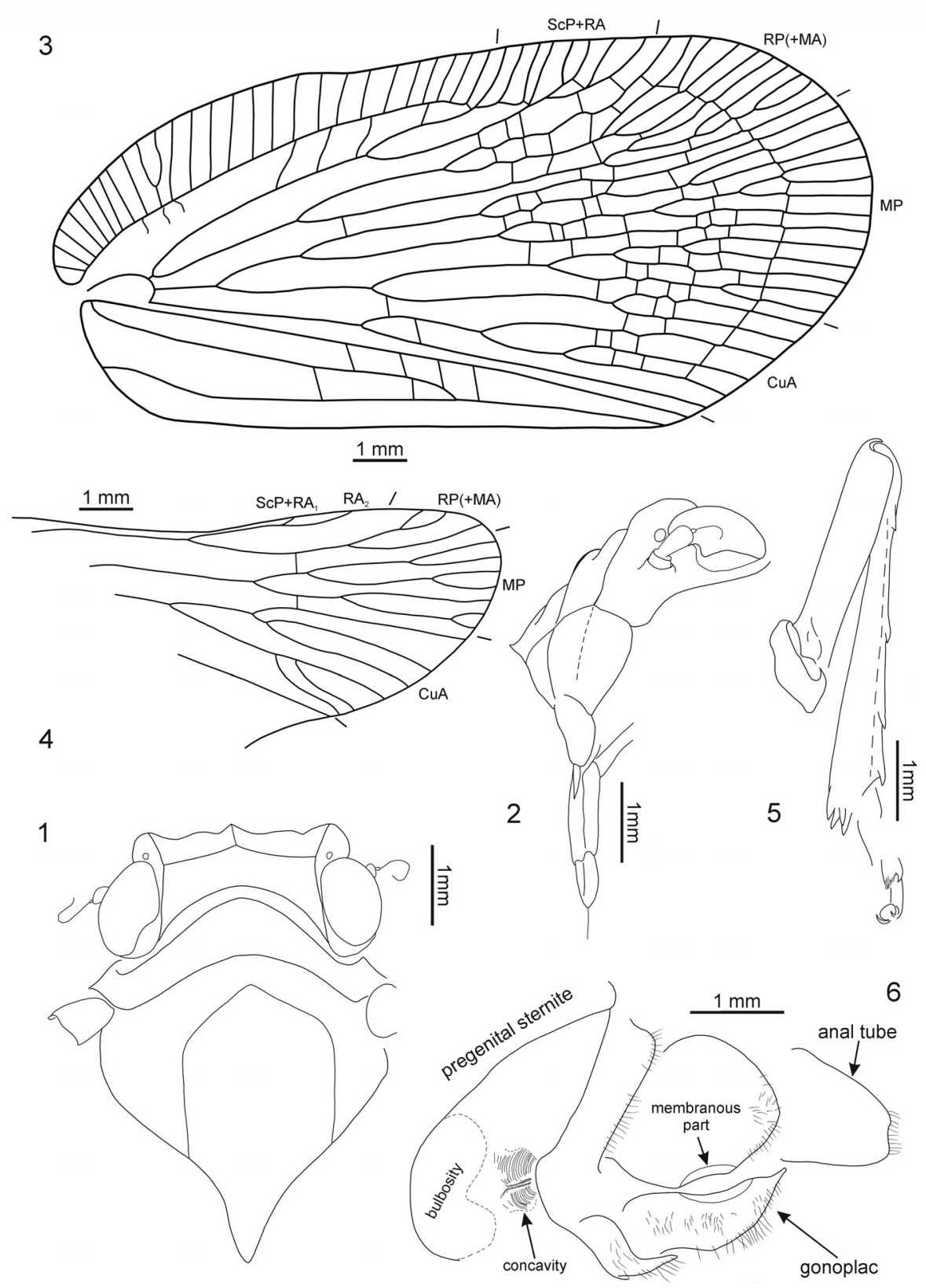

FIGURE 2. Gedanotropis sontagae gen. et sp. nov. 1, Head, pronotum and mesonotum, dorsal view; 2, face, ventrolateral view; 3, tegmen (venation partly reconstructed); 4, hind wing (visible portion); $\mathbf{5}$, left hind leg; and $\mathbf{6}$, female genital block.

could be absent or partly developed. The variability is observed also in presence or absence and degree of development of transverse veinlets on clavus. Also the armature of metatibia vary strongly among tribes of Tropiduchidae. In Fennah's 1982 classification scheme a combination of male gonostyli and female gonoplac is an important character at the tribal level. Unfortunately, only female characters are available here. Rounded gonoplac is characteristic for the Elicinae, but lack of any teeth or denticles and membranous median portion are apomorphic character states for the new tribe.

Type horizon. Middle Eocene.

Genus GEDANOTROPIS gen. nov. zoobank.org/9284D976-9799-4E2C-A353-765DD4A50750

Type species. Gedanotropis sontagae sp. nov., designated herein and by monotypy. 


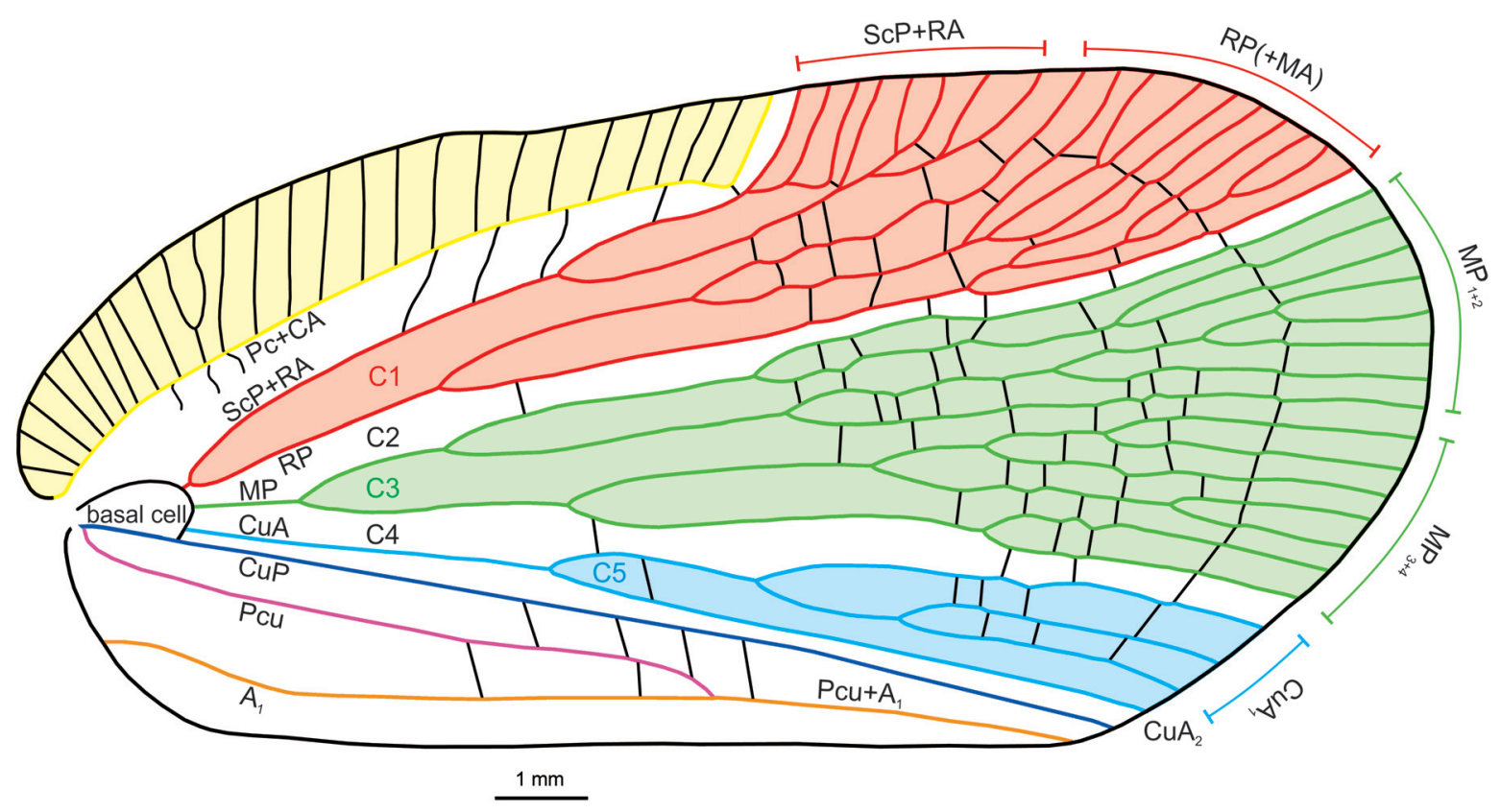

FIGURE 3. Gedanotropis sontagae gen. et sp. nov. tegmen venation with veins, cells and areas indicated.

Etymology. Generic name is derived from old Latin name of City of Gdańsk, Gedanum, and Ancient Greek noun тро́т-Іऽ; тро́тাठ-оS (tróp-is, trópid-os) meaning keel of the ship, and being the core for generic name Tropiduchus (from Ancient Greek трóm-ıৎ (trop-is) and ह̌xw (ékhō): have, hold, possess, of property). Gender: masculine; 3rd declension.

Diagnosis. Head with compound eyes narrower than pronotum. Vertex wider than long in mid line, with all margins carinate. Frons with lateral margin elevated. Mesonotum with lateral carinae connected at base. Base of tegmen strongly curved; costal area reaching half of tegmen length, wide at base, tapered apicad, with regular transverse veinlets; postcostal cell distinctly narrower than costal area; main stems forked in following sequence: $\mathrm{ScP}+\mathrm{R}(+\mathrm{MA})$ forks first very shortly after the basal cell; MP forks later but very early in the first fifth on the tegmen separating a very long C3; CuA forks at mid length of clavus; all stems forked again in basal $1 / 3$ of tegmen length; single apical line of transverse veinlets present. Hind wing with two transverse veinlets $\mathrm{rp}-\mathrm{mp}$ and $\mathrm{mp}$-cua present. Metatibia with 5 lateral spines and 8 apical teeth. Apex of anal tube exceeding posterior margin of gonoplac. Lateral portions of female pregenital sternite narrower than median portion, tapering laterad.
Description. Head with compound eyes about as wide as mesonotum; vertex wider than long in mid line, with all margins distinctly carinate; anterior margin widely quoin-shaped, posterior margin arcuately incised, lateral margins merely longer than length at midline, parallel; disc of vertex without median carina (Figures 2.2, 4.1, 4.3). Vertex and frons connected at right angle. Frons with lateral margins elevated, median carina keel-shaped. Disc of frons between median carina and lateral margins with parallel ledges, not reaching dorsal margin nor frontoclypeal suture. Compound eyes bulging, higher than wide in lateral view, with small posteroventral callus. Ocellus present, at cross of anterior and lower margins lines. Antennal fovea elevated, placed under the compound eye, close to it ventral margin, scapus as long as wide, pedicel about twice as long as wide, a bit wider apically than at base, antennal plate organs present in apical and dorsal portion to half of pedicel length (Figures 2.1-2, 4.1-2, 4.5).

Frontoclypeal suture angulate. Clypeus with elevated median carina and without lateral carinae; median portion, below frontoclypeal suture, slightly convex (Figures 2.2, 4.2, 4.5).

Rostrum (Figure 4.5) 4-segmented, all segments well sclerotised; 1st basal segment longer than wide, 2nd basal segment the shortest, with triangular membranous part at base, subapical seg- 

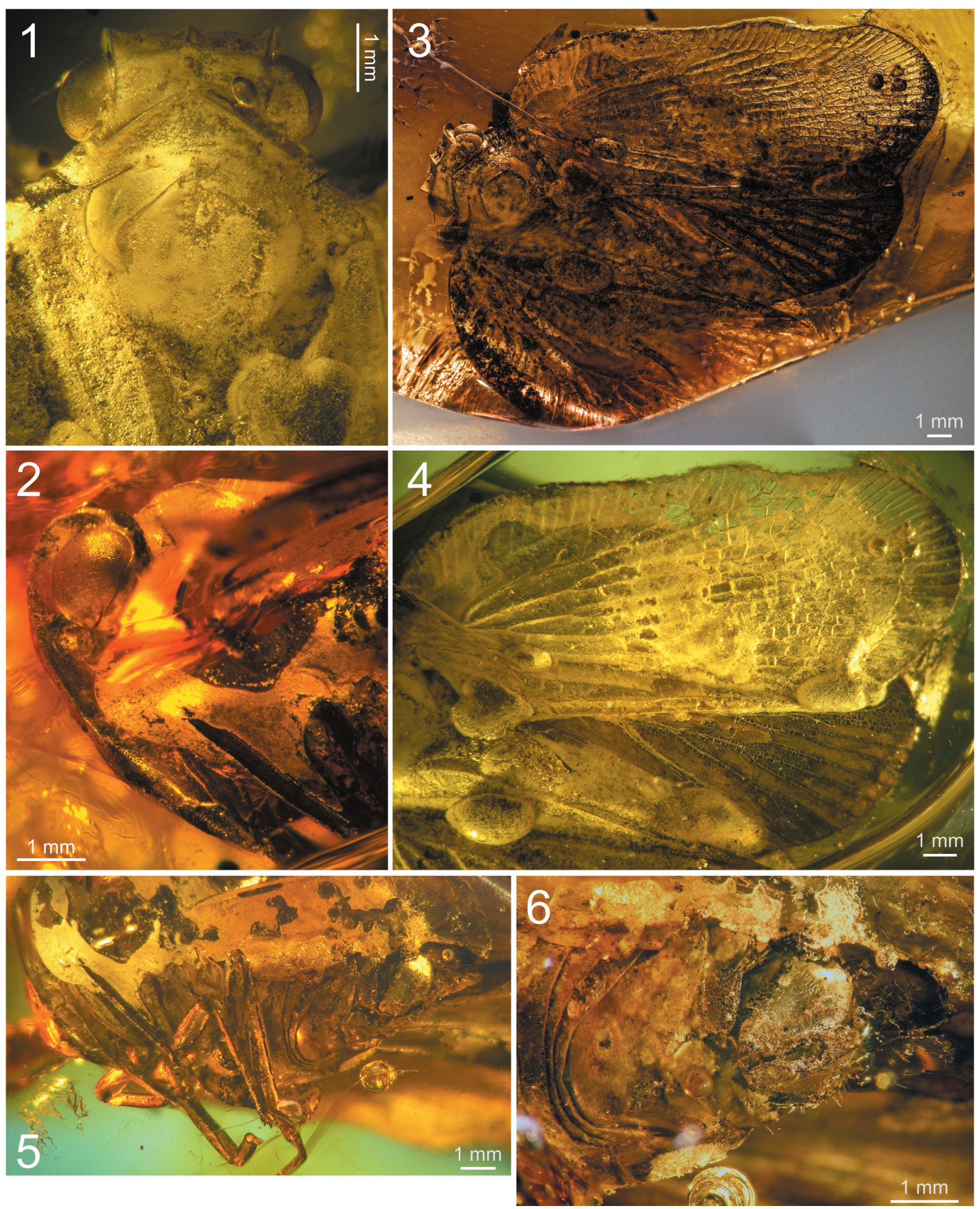

FIGURE 4. Gedanotropis sontagae gen. et sp. nov. 1, Anterior portion of the body; 2 , head in lateral view; $\mathbf{3}$, habitus of the specimen; 4, tegmen and hind wing; 5, body in lateroventral view; and 6, female genital block (ventrolateral view). 
ment the longest, apical segment distinctly longer than wide, shorter than subapical one; apex of rostrum reaching base of hind coxae.

Pronotum (Figures 2.1, 4.1, 4.3) longer than vertex in mid line, anterior margin angulately incised, with apex reaching half of compound eyes length; posterior margin widely arcuate; disc of pronotum delimited by strongly elevated, carinate anterior margin, not stepping on paradiscal field of pronotum, posterior margin distinctly elevated, disc of pronotum lacking median carina; plane of disc of pronotum above plane of disc of vertex.

Mesonotum (Figures 2.1, 4.1, 4.3) longer in mid line than cumulative length of vertex and pronotum, anterior margin rounded, posterior margin angulate; disc of mesonotum with plane area distinctly elevated above plane area of pronotum, flat, delimited by lateral carinae connected at base; disc of mesonotum distinctly shifted from anterior margin, lateral margins widely diverging posterolaterad to the level of lateral angles of mesonotum, then angulately curved, converging posteromediad at short distance and not reaching posterior margin of mesonotum.

Tegula huge, without carina.

Profemur (Figure 4.5) slightly laterally compressed, subpentagonal in cross section, dorsal margin with row of short setae, anteroventral ridge with row of short thorns apically; protibia subtriangular in cross section; basitarsomere short, midtarsomere and apical tarsomere subequal in length, tarsal claws huge, arolium wide.

Mesofemur (Figure 4.5) slightly longer than profemur, subpentagonal in cross section, dorsal margin with row of short setae, anteroventral ridge with row of short thorns apically; mesotibia longer than protibia, subtriangular in cross section; basitarsomere short, midtarsomere and apical tarsomere subequal in length, tarsal claws huge, arolium wide.

Metacoxa large, metacoxal process invisible.

Metafemur (Figure 2.5) slightly flattened, ventral margins ridged; metatibia long, with 5 lateral spines (the basal one not clear on left metatibia) and a row of 8 apical teeth; basitarsomere longer than cumulative length of mid- and apical tarsomeres, with row of 7 apical teeth; midtarsomere short, with lateral teeth distinct, median lobe distinct, with apical margin extending apices of lateral teeth, covered with dense and strong setae; apical tarsomere shorter than basitarsomere, tarsal claws distinct with subbasal teeth with two setae, arolium wide.
Tegmen (Figures 2.3, 3, 4.3, 4.4) about 2.5 times as long as wide, membranous, with dense and distinct venation. Costal margin strongly curved at base, then almost straight, parallel to posterior margin; anteroapical angle widely rounded, apical margin round, with breaking point at about median axis of tegmen, posteroapical angle widely angulate, tornus (postclaval margin) absent, apex of clavus exceeding $3 / 4$ of tegmen length, clavus closed, acute. Costal area well developed, very wide at base, tapering toward apex, intersected with slightly oblique veinlets, slightly exceeding half of tegmen length. Postcostal cell narrower than costal area, tapering distad, with a few transverse veinlets. Basal cell longer than wide. Stem ScP+RA and stem RP(+MA) leaving basal cell with a very short stalk, stem ScP+RA distinctly curved at base, forked distad of stem $\mathrm{RP}(+\mathrm{MA})$ forking, reaching anterior margin basad of anteroapical angle with 8 terminals; stem $\mathrm{RP}(+\mathrm{MA})$ forked at level of branch $\mathrm{MP}_{1+2}$ forking, then both branches forked again on corium, slightly basad of end of costal area; branches reaching anteroapical angle with 10 terminals. Stem MP short, forked at distance of basal cell length; branch $\mathrm{MP}_{1+2}$ forked basad of branch $\mathrm{MP}_{3+4}$ forking, branch $\mathrm{MP}_{3+4}$ forked slightly apicad of stem CuA forking; branch $\mathrm{MP}_{1}$ forked on corium, slightly basad of branch $\mathrm{MP}_{2}$ forking, then forked basad of apical line of veinlets, reaching margin with 3 terminals; branch $\mathrm{MP}_{2}$ forked on corium, then on membrane, basad of apical line of veinlets, reaching margin with 5 terminals; branch $\mathrm{MP}_{3}$ forked on corium and membrane, reaching margin with 5 terminals; branch $\mathrm{MP}_{4}$ forked on corium, apical of first forking of branch $\mathrm{MP}_{3}$, reaching margin with 2 terminals; stem MP reaching apical margin with 15 terminals. Stem CuA forked slightly basad of branch $\mathrm{MP}_{3+4}$ forking, branch $\mathrm{CuA}_{1}$ forked on corium and membrane, reaching margin with 3 terminals; branch $\mathrm{CuA}_{2}$ single. Claval veins $\mathrm{Pcu}$ and $A_{1}$ fused at about $1 / 2$ of tegmen length, fused stem $\mathrm{Pcu}+\mathrm{A}_{1}$ reaching posterior margin of clavus slightly basad of apex of clavus.

Cell C1 longer than cell C3, closed posteriorly with transverse veinlet placed apicad of $\mathrm{ScP}+\mathrm{R}$ and $\mathrm{RP}_{1}(+\mathrm{MA})$ forkings. Cell $\mathrm{C} 2$ shorter than cell $\mathrm{C} 1$, closed with transverse veinlet $1 \mathrm{r}$-mp apicad of $\mathrm{RP}(+\mathrm{MA})$ and $\mathrm{MP}_{1+2}$ forkings. Cell $\mathrm{C} 3$ about 1.5 times as long as cell $\mathrm{C} 2$, closed with transverse veinlet $1 \mathrm{im}$ placed apicad of stem $\mathrm{MP}_{2}$ first forking. Cell $\mathrm{C} 4$ longer than cell $\mathrm{C} 2$, closed by transverse 
veinlet mp-cua placed slightly apicad of branch $\mathrm{MP}_{3+4}$ and CuA forkings. Cell C5 the shortest, closed with icua veinlet basad of claval veins junction.

Several not regularly dispersed veinlets on remigium present, and arcuate apical line of veinlets present. Clavus with four transverse veinlets between CuP and Pcu, two transverse veinlets between $P c u$ and $A_{1}$ basad of junction.

Functional nodal line of transverse veinlets absent; corium with sparse transverse veinlets; membrane with dense and irregular net of transverse veinlets, apical line of veinlets distinctly developed. Apical cells longer than wide.

Hind wing (Figures 2.4, 4.3-4) slightly shorter than forewing, wide, without costal area, with angulate anteroapical angle and only 2 transverse veinlets rp-mp, and mp-cua. Stem ScP+R $(+M A)$ forked basad of wing coupling lobe, $\mathrm{ScP}+\mathrm{RA} \mathrm{A}_{1}$ short, oblique, reaching margin at level of transverse veinlets $r p-m p$ and $m p$-cua; terminal $\mathrm{RA}_{2}$ reaching margin distinctly basad of anterior angle of hind wing with single terminal. Branch $\mathrm{RP}(+\mathrm{MA})$ forked from $\mathrm{ScP}+\mathrm{R}(+\mathrm{MA})$ distinctly basad of $r p-m p$ veinlet, at level of branch $\mathrm{CuA}_{1}$ first forking forked distinctly apicad of rp-mp veinlet; branch $\mathrm{RP}_{1+2}$ forked slightly apicad of $\mathrm{rp}$-mp veinlet, with two terminals reaching margin basad of anteroapical angle; terminal $\mathrm{RP}_{3}(+\mathrm{MA})$ reaching margin at anteroapical margin. Stem MP forked apicad of stem $\mathrm{ScP}+\mathrm{R}$ forking, at level of branch $\mathrm{CuA}_{1}$ first forking; branch $\mathrm{MP}_{1+2}$ forked slightly apicad of transverse veinlet rp-mp, basad of branch $\mathrm{MP}_{3+4}$ forking, reaching margin with four terminals $\mathrm{MP}_{1 \mathrm{a}}$ and $\mathrm{MP}_{1 \mathrm{~b}}$, forking basad of terminals $\mathrm{MP}_{2 \mathrm{a}}$ and $\mathrm{MP}_{2 \mathrm{~b}}$ forking; branch $\mathrm{MP}_{3+4}$ forked apicad of branch $\mathrm{MP}_{1+2}$ forking, terminal $\mathrm{MP}_{3}$ single, terminal $\mathrm{MP}_{4}$ forked just before apex; stem $M$ reaching margin with 7 terminals in total. Stem CuA multiforked, first furcation slightly basad of stem ScP+R forking; branch $\mathrm{CuA}_{1}$ forked again at level of stem MP furcation, branch $\mathrm{CuA}_{1 \mathrm{a}}$ reaching margin as single terminal, branch $\mathrm{CuA}_{1 \mathrm{~b}}$ forked again distinctly basad of $\mathrm{mp}$-cua veinlet, reaching margin with two terminals; branch $\mathrm{CuA}_{2}$ forked sequentially downwards, first terminal, $\mathrm{CuA}_{2 \mathrm{c}}$ forked slightly apicad of branch $\mathrm{CuA} \mathrm{Ab}_{1 \mathrm{~b}}$ forking, at level of branch ScP+RA forking, second terminal, $\mathrm{CuA}_{2 b}$ forked at level of transverse veinlets rp-mp and mp-cua, terminal $\mathrm{CuA}_{2 a}$ parallel to $\mathrm{CuA}_{1 \mathrm{~b} 2}$, terminals $\mathrm{CuA}_{2 \mathrm{~b}}$ and $\mathrm{CuA}_{2 \mathrm{c}}$ parallel, shifted to end of CuP. Stem CuP single, reaching margin basad of end of $\mathrm{RA}_{2}$ terminal.

Female terminalia (Figures 2.6, 4.6). Pregenital sternite with distinct transverse bulbosity at base, and two eminences; lateral portions tapering laterad, directed posterolaterally; posterior margin strongly deflected, basally of this deflection two rounded cavities, transversely striated, incised deeply at margin deflection, separated by triangular ridge. Anal tube elongate, oval, with apex exceeding posterior margin of gonoplacs. Gonoplac rounded, with obtusely rounded pyramidal eminence medially; posterior margin with narrow, elongate, membranous part, placed below half of gonoplac height, without denticles (smooth).

Type horizon. Middle Eocene.

\section{Gedanotropis sontagae sp. nov.}

Figures 2-4

\section{zoobank.org/911FDE86-67E7-4AF3-9D7C-524F2F920843}

Type material. Holotype: female, Baltic amber inclusion, MAI UG 508762; deposited in Museum of Amber Inclusions, University of Gdańsk, Gdańsk, Poland.

Etymology. The specific name is dedicated to our great friend, Dr. Elżbieta Sontag, eminent specialist on fossil and recent Diptera: Ceratopogonidae, Curator of Museum of Amber Inclusions, University of Gdańsk, Gdańsk, Poland.

Type horizon. Middle Eocene (Lutetian).

Type locality. Baltic amber (secondary deposit, Gulf of Gdańsk area).

Diagnosis. Lateral margins of vertex about 1.3 times as long as vertex in mid line. Tegmen with 9 terminals of branch ScP+RA, 10 terminals of branch RP, 15 terminals of branch MP. Cell C1a shorter than cell $\mathrm{C} 1 \mathrm{~b}$; cell $\mathrm{C} 3 \mathrm{a}$ slightly shorter than cell C3b, cell C5' open to the margin; cells C2 and C4 closed, with transverse veinlets well anteriad of half of tegmen length. Combined length of hind leg mid- and apical tarsomere exceeding length of basitarsomere.

Description. Plane of vertex at right angle to plane of frons. Metatibio-tarsal formula $8: 7: 2[+$ setiferous lobe]. Hind wing with stem MP reaching margin with 7 terminals, branch $\mathrm{CuA}_{1}$ with 3 terminals, branch $\mathrm{CuA}_{2}$ with 3 terminals. Female anal tube slightly longer than broad.

Measurements (measurements could be slightly biased due to optical properties of amber): Total length $16.5 \mathrm{~mm}$, length of body $12.8 \mathrm{~mm}$. Head with compound eyes $3.3 \mathrm{~mm}$; vertex at anterior margin $18.75 \mathrm{~mm}$, at posterior margin $2.0 \mathrm{~mm}$, $0.48 \mathrm{~mm}$ long at mid line, $0.62 \mathrm{~mm}$ long measured 
at lateral margin. Frons at mid line $2.35 \mathrm{~mm}$ long, at lateral margin $2.7 \mathrm{~mm}$ long; clypeus $0.96 \mathrm{~mm}$ long. Rostrum $2 \mathrm{~mm}$ long, subapical segment 1.05 $\mathrm{mm}$, apical segment $0.6 \mathrm{~mm}$ long. Pronotum 0.75 $\mathrm{mm}$ long at mid line, $3.85 \mathrm{~mm}$ wide. Mesonotum $3.5 \mathrm{~mm}$ long at mid line, $3.2 \mathrm{~mm}$ wide. Tegmen $14.7 \mathrm{~mm}$ long, $6.8 \mathrm{~mm}$ wide at widest point. Profemur $2.5 \mathrm{~mm}$ long, protibia $3.0 \mathrm{~mm}$ long, protarsus $1.15 \mathrm{~mm}$ long, basitarsomere $0.3 \mathrm{~mm}$, mid tarsomere $0.35 \mathrm{~mm}$, apical tarsomere with claws 0.75 $\mathrm{mm}$; Mesofemur $2.7 \mathrm{~mm}$ long, mesotibia $3.4 \mathrm{~mm}$ long, mesotarsus $1 \mathrm{~mm}$ long, basitarsomere 0.35 $\mathrm{mm}$, mid tarsomere $0.35 \mathrm{~mm}$, apical tarsomere with tarsal claws $0.75 \mathrm{~mm}$. Metafemur $2.55 \mathrm{~mm}$ long, metatibia $4.6 \mathrm{~mm}$ long, metatarsus $1.5 \mathrm{~mm}$ long, basitarsomere $0.85 \mathrm{~mm}$ long, midtarsomere $1.25 \mathrm{~mm}$ long, apical tarsomere $1.25 \mathrm{~mm}$ long, combined length of basi- and mitarsomeres $1 \mathrm{~mm}$.

\section{DISCUSSION}

\section{Classification and Morphological Characters}

Some Tropiduchidae superficially resemble Dictyopharidae but the small second metatarsus bearing a distinct spine on each side allows an easy distinction. However, the "classic" two characters differentiating Tropiduchidae from other Fulgoroidea families (Brues et al., 1954; O'Brien and Wilson, 1985; Naumann et al., 1991; O'Brien, 2002),-i.e., 1) presence of the groove or fine line separating the apex of the mesonotum (mesoscutellum) from the rest of the mesonotal disc and 2) apex of tegmina bearing more numerous veinlets set off by the nodal line (in most representatives) appeared to be of limited value. Moreover, no clear idea about the relationships of the recognised tribes within the family has ever been presented, and no strong evidences for monophyly of these taxonomic units are available.

Classification and subdivisions of the family have been proposed several times, since pioneering works by Melichar (1914) and Muir (1923), to the most recent higher classification proposed by Fennah (1982), who listed 120 genera discriminated into 15 tribes. Up to date183 genera, distributed within 24 tribes separated within 2 subfamilies, are known (Gnezdilov, 2013b, Bourgoin, 2017). The subfamily Tropiduchinae Stål, 1866 to which all tribes listed by Fennah (1982) belong, represents the so-called "typical tropiduchid" with an elongate ovipositor and elongate gonoplacs with marginal teeth (except the genus Durium Stål, 1861) and with a triangular (in shape of isosceles triangle) posterior connective lamina of gonapophyses IX (Gnezdilov, 2003, fig. 35). The subfamily Elicinae Melichar, 1915 (senior synonym of Gaetuliina Fennah, 1978) can be distinguished by rounded (hemispheric in Elicini Melichar, 1915 or flat in Parathisciini; Gnezdilov, 2013b) gonoplacs without teeth or with small denticles and by elongate (not triangular) posterior connective lamina of gonapophyses IX (Gnezdilov, 2013b).

One important and particularly noticeable feature of Gedanotropis gen. nov. is absence of the metacoxal process. In modern Fulgoroidea it is always present as a spine-like, sometimes sulcate or spatulate.

\section{Disparity in Extinct and Extant Tropiduchid}

As for modern tropiduchids, diversity and disparity of Tropiduchidae in the Eocene Baltic amber remain unexplained. However, the fossils from Baltic amber in majority of cases belong to separate and different lineages from the present tribes. This could result from several reasons. First, it could be the real indication of particular diversity and disparity of Tropiduchidae in the habitats of the Baltic amber forests. Tropiduchinae are represented among Baltic amber inclusions only by Jantaritambini while all other taxa belong to Elicinae: Elicini, Austrini, Patollini and Gedanotropidini trib. nov. described above. Except for Elicini (Tritophania patruelis Jacobi, 1938) all tribes recorded from Baltic amber are exclusive for this resin (Appendix 2). Second, the fossil record of the other Tropiduchidae tribes is scarce and most of them have not been recognised and reported. Third, the evolution and adaptation of many of Tropiduchidae taxa were related with host plants lineages rapidly evolving during the Palaeogene and these fossils had low fossilisation potential.

\section{Issidisation and Flatidinisation Syndromes}

It must be noted that similarly to modern Tropiduchinae and Elicinae, among Baltic amber inclusions, the forms with 'issidisation syndrome' (Gnezdilov, 2013a), are present, i.e., Austrini and Patollini. Such kind of body constitution, i.e., stocky, almost ovoid shape, with brachypterous wings, were already explained by Fennah (1967) as factors allowing to save water by reducing the body surface, facilitating cold resistance and female fecundity, and enhancing the hopping ability, whereas brachyptery would also facilitate mobility in the dense and coarse fynbos vegetation which would hinder flight. Denser integument and a more compact body were also regarded as morphological adaptations to arid climate in planthop- 
pers of the subfamily Orgeriinae Fieber, 1872 of the family Dictyopharidae Spinola, 1839 (Emeljanov, 1980). Brachyptery in true bugs of the family Nabidae Costa, 1852 was noted as characteristic of species living in low and sparse vegetation (Kerzhner, 1981). Among fossils from the Baltic amber brachypterous forms were recorded also among Cicadellidae leafhoppers (Szwedo, 2002; Dietrich and Gonçalves, 2014).

The newly described genus Gedanotropis represents the tribe with fully developed wings, and lack the "issidisation syndrome", similarly to the early described genus Tritophania Jacobi, 1938, representing also fully winged Elicini. In reverse, the new fossil expresses a particular characteristic tegmina shape: subquadrate shape of tegmen, anterior portion of costal margin strongly curved and shifted anteriad, costal margin undulate, polymerization of longitudinal veins and tegmina tent-like fashioned or hold flat (horizontally). Such constitution is known in various other planthopper families (Fulgoridae, Ricaniidae, Flatidae) and is quite common among other representatives of the family Flatidae Spinola, 1839, e.g., subfamily Flatoidinae Melichar, 1901. As for 'issidisation' we recognise here a special morphological trend that we call 'flatoidinisation'. It could be assumed per analogiam to habitats of modern representatives of Flatoidinae, that Gedanotropidini inhabited forests and "flatoidinisation" would indicate their analogous mimetic abilities (O'Brien, 2002) to hide on tree-trunks or lichens covering the bark.

\section{Higher Fulgoroidea Radiation}

The ancestral forms of higher fulgoroid planthoppers are difficult to determine since their fossil record is scarce (Shcherbakov, 2006). According to the results of molecular analyses (Urban and Cryan, 2007), families of the issidoid group are young (advanced) taxa. Indeed, fossil representatives of Nogodinidae have been known only since the late Palaeocene (Shcherbakov, 2006), those of Tropiduchidae, since the Late Cretaceous (Szwedo, 2009; Nicholson et al., 2015), those of Issidae, since the Eocene (Gnezdilov and Bourgoin, 2016), Caliscelidae since the Miocene (Bourgoin et al., 2016) whereas no fossil data are available for Acanaloniidae Amyot and AudinetServille, 1843 (Szwedo, 2002; Shcherbakov, 2006). According to Szwedo (2002), families of the issidoid group must have originated at the Cretaceous-Palaeogene boundary (66 Mya) and diverged widely during the Eocene to Miocene, while Shcherbakov (2006) placed the latest radia- tion of higher fulgoroid families, after the Cretaceous-Palaeogene crisis. However, these fossils attest only for the minimum age of the respective lineage. Moreover, insects inhabiting mountain and desert regions have minimal chances to be preserved as fossils (Zherikhin, 1980). Besides, Wang M.L. and Bourgoin (2017, pers. comm., under preparation) place the origin of Issidae at least before 70 Mya.

\section{Palaeoenvironments}

The forests, in which resin transformed into Baltic amber, have been spreading on the vast area for about 10 million years (Wolfe et al., 2009, 2016; Szwedo, 2012). The differentiation of the forests was influenced by number of factors: geographic and topographic position, soils and water, temperature, insolation, seasonality, climate changes, etc. (Archibald and Farrell, 2003; Archibald et al. 2013; Szwedo, 2012; Szwedo and Kania, 2015; Wolfe et al., 2016). Palaeoclimatic and palaeoecological interpretations result in many questions regarding the variability of Baltic amber forest(s) habitats and environments (e.g., Alexeev and Alexeev, 2016; Perkovsky, 2016; Sadowski et al., 2016a, 2016b; Schmidt et al., 2016; Alexeev, 2017). However, it is probable that dry and open habitats, as e.g., sparse and open forests or low vegetation areas with a few resiniferous trees or at least on borderland with amber producing trees, were present in the area and at time of the Baltic amber deposit alimentation (Kohlmann-Adamska 2001; Szwedo, 2012; Szwedo and Drohojowska, 2015).

The observed high diversity of Tropiduchidae lineages, also reflected in the Baltic amber inclusions with separated fossil lineages, is interesting to note. If it confirms an early radiation of the family, it probably also reflects taphonomic factors linked to a diverse origin of the Baltic amber inclusions. Indeed, thanatocoenosis of Baltic amber is a a result of long, complicated and still little understood processes (Zherikhin, 2002; MartínezDelclòs et al., 2004; Szwedo and Sontag, 2009) and yield fossil assemblage belonging to various ecosystems and different time-slices. Better understanding of these taphonomic factors remains essential for determining the exact palaeoenvironments of these fossils, their interactions and role in these ancient ecosystems, and particularly with plants which are at the origin of amber inclusions. Nevertheless, further studies on Tropiduchidae from Baltic amber as well as fossils from other contemporaneous deposits, are needed. Phylogenetic 
analysis based on morphological, palaeoentomological and molecular studies is urgently needed to solve the questions of features, definition and content of Tropiduchidae and its subordinate taxa.

\section{ACKNOWLEDGEMENTS}

We wish to thank cordially J. Damzen (MB Amber Inclusions, Vilnus, Lithuania) for bringing the specimen to our attention and E. Sontag (Museum of Amber Inclusions, University of Gdańsk, Gdańsk, Poland) for her help during the study of the material. Also we thank A. Klikowicz,
M.Sc. Eng. (Amber Laboratory of International Amber Association, Gdańsk, Poland) for the help with FT-IR analysis. We express our sincere thanks to reviewers for their comments and suggestions. We are deeply indebted to T. Bourgoin (MNHN, Paris, France) and D. Świerczewski (Jan Długosz Academy, Częstochowa, Poland) for valuable discussions and comments on earlier drafts of this paper. We wish to thank also M. Hyžný, Handling Editor of PE, for all the comments and suggestions improving this paper.

\section{REFERENCES}

Alexeev, V.I. 2017. Coleoptera from the middle-upper Eocene European ambers: Generic composition, zoogeography and climatic implications. Zootaxa, 4290:401-443. https://doi.org/ 10.11646/zootaxa/4290.3.1

Alexeev, V.I. and Alexeev, P.I. 2016. New approaches for reconstruction of the ecosystem of the Eocene amber forest. Biology Bulletin, 43:75-86. https://doi.org/10.1134/ s1062359016010027

Amyot, C.J.B. and Audinet-Serville, J.G. 1843. Deuxième partie. Homoptères. Homoptera Latr. Histoire Naturelle des insectes. Hemiptères. Librarie encyclopédique de Roret, Paris.

Archibald, S.B. and Farrell, B.D. 2003. Wheeler's dilemma. Acta Zoologica Cracoviensia, 46(suppl. Fossil Insects):17-23.

Archibald, S.B., Greenwood, D.R., and Mathewes, R.W. 2013. Seasonality, montane beta diversity, and Eocene insects: Testing Janzen's dispersal hypothesis in an equable world. Palaeogeography, Palaeoclimatology, Palaeoecology, 371:1-8. https://doi.org/10.1016/ j.palaeo.2012.10.043

Bartlett, C.R., O'Brien, L.B., and Wilson, S.W. 2014. A review of the planthoppers (Hemiptera: Fulgoroidea) of the United States. Memoirs of the American Entomological Society, 50:1-287.

Bisulca, C., Nascimbene, P.C., Elkin, L., and Grimaldi, D.A. 2012. Variation in the deterioration of fossil resins and implications for the conservation of fossils in amber. American Museum Novitates, 3734:1-19.

Bogdasarov, M.A. 2010. Yantar i drugie iskopaemye smoly Evrazii. Monografiya [Amber and Other Fossil Resins of Eurasia. The Monograph]. Brestskiï Gosudarstvennyï Universitet imeni A.S. Pushkina [Brest National A.S. Pushkin University], Brest. (In Russian)

Bourgoin, T. 2017. FLOW (Fulgoromorpha Lists on The Web): A world knowledge base dedicated to Fulgoromorpha. V.8, updated 01 October 2017. http://www.hemipteradatabases.org/flow/

Bourgoin, T., Wang, R.R., Asche, M., Hoch, H., Soulier-Perkins, A., Stroinski, A., Yap, S., and Szwedo, J. 2015. From micropterism to hyperpterism: Recognition strategy and standardized homology-driven terminology of the forewing venation patterns in planthoppers (Hemiptera: Fulgoromorpha). Zoomorphology, 134:63-77. https://doi.org/10.1007/s00435-014-0243-6

Bourgoin, T., Wang, R.R., and Gnezdilov, V.M. 2016. First fossil record of Caliscelidae (Hemiptera: Fulgoroidea): A new Early Miocene Dominican amber genus extends the distribution of Augilini to the Neotropics. Journal of Systematic Palaeontology, 14:211-218. https://doi.org/10.1080/14772019.2015.1032376

Brożek, J., Bourgoin, T., and Szwedo, J. 2006. The interlocking mechanism of maxillae and mandibles in Fulgoroidea (Insecta: Hemiptera: Fulgoromorpha). Polish Journal of Entomology, 75:239-253.

Brues, C.T., Melander, A.L., and Carpenter, F.M. 1954. Classification of insects. Keys to the living and extinct families of insects, and to the living families of other terrestrial arthropods. Bulletin of the Museum of Comparative Zoology, 108:i-v, 1-917. 
Chang, Z.M. and Chen, X.S. 2014a. Review of the planthopper genus Ommatissus Fieber (Hemiptera: Fulgoromorpha: Tropiduchidae) with descriptions of three new species from China. Zootaxa, 3856:241-252. https://doi.org/10.11646/zootaxa.3856.2.5

Chang, Z.M. and Chen, X.S. 2014b. A new genus of the tribe Eporini (Hemiptera: Fulgoromorpha: Tropiduchidae) with description of three new species from Yunnan, China. Florida Entomologist, 97:1602-1612. https://doi.org/10.1653/024.097.0434

Constant, J. 2015. A new species of Bananellodes Strand, 1928 from Namibia (Hemiptera: Fulgoromorpha: Tropiduchidae). Belgian Journal of Entomology, 32:1-13.

Costa, A. 1852. Cimicum regni neapolitani. Centuria tertia et quartae fragmentum. (Publisher unknown), Napoli.

Dietrich, C.H. and Gonçalves, A.C. 2014. New Baltic amber leafhoppers representing the oldest Aphrodinae and Megophthalminae (Hemiptera, Cicadellidae). European Journal of Taxonomy, 74:1-13. https://doi.org/10.5852/ejt.2014.74

Dlabola, J. 1974. Ergebnisse der Tschechoslowakisch-Iranischen entomologischen Expedition nach dem Iran 1970. Nr. 3: Homoptera, Auchenorrhyncha (1. Teil). Acta Entomologica Musei Nationalis Pragae, 6 (suppl.):29-73.

Emeljanov, A.F. 1980. Filogeniya i evolyutsiya nosatok podsemeïsva Orgeriinae (Homoptera, Dictyopharidae) [Phylogeny and evolution of planthoppers of the subfamily Orgeriinae (Homoptera, Dictyopharidae)]. Chteniya pamyati N.A. Kholodkovskogo. Doklad na tridtsat vtorom ezhygodnom chtenii 10 apreliya 1979 goda [N.A. Kholodkovsky Memorial Lectures, Talk for Thirty Second Annual Memorial Lecture April 10, 1979], 32:1-95. (In Russian)

Fennah, R.G. 1945. The Tropiduchidae of the Lesser Antilles (Homoptera: Fulgoroidea). Proceedings of the Entomological Society of Washington, 47:137-167.

Fennah, R.G. 1967. New and little known Fulgoroidea from South Africa (Homoptera). Annals of the Natal Museum, 18:655-714.

Fennah, R.G. 1978. The higher classification of the Nogodinidae (Homoptera, Fulgoroidea) with the description of a new genus and species. Entomologist's Monthly Magazine, London, 113:113-118.

Fennah, R.G. 1982. A tribal classification of the Tropiduchidae (Homoptera: Fulgoroidea), with the description of a new species on tea in Malaysia. Bulletin of Entomological Research, 72:631-643.

Fieber, F.X. 1872. Katalog der europäischen Cicadinen, nach Originalien mit Benützung der neuesten Literatur. Druk und Verlag von Carl Gerold's Sohn, Wien.

Fletcher, M.J. 2008. A key to the genera of Ricaniidae (Hemiptera: Fulgoromorpha) recorded in Australia with notes on the Australian fauna, including a new species of Epithalamium Kirkaldy. Australian Journal of Entomology, 47:107-120. https://doi.org/10.1111/j.14406055.2008 .00636

Gnezdilov, V.M. 2003. Obzor semeïstva Issidae (Homoptera, Cicadina) evropeïskoï fauny z zamiechaniami o stroeni yaïtseklada fulgoroidnykh tsikadovykh [Review of the family Issidae (Homoptera, Cicadina) of the European fauna, with notes on the structure of ovipositor in planthoppers]. Chteniya pamyati N.A. Kholodkovskogo, St. Petersburg [N.A. Kholodkovsky Memorial Lectures, St. Petersburg], 56:1-145. (In Russian with English summary)

Gnezdilov, V.M. 2007. On the systematic positions of the Bladinini Kirkaldy, Tonginae Kirkaldy, and Trienopinae Fennah (Homoptera, Fulgoroidea). Zoosystematica Rossica, 15:293-297.

Gnezdilov, V.M. 2012a. On the taxonomy of some Fulgoroidea (Hemiptera). Proceedings of the Zoological Institute RAS, 316:239-247.

Gnezdilov, V.M. 2012b. A new stenopterous genus of the tribe Gaetuliini Fennah (Hemiptera, Fulgoroidea, Tropiduchidae) from Southern Africa - particular intercontinental convergence. African Invertebrates, 53:637-644.

Gnezdilov, V.M. 2013a. Issidizatsiya fulgoroidnykh tsikadovykh (Homoptera, Fulgoroidea) kak proyavlenie parallel'noï adaptivnoï radiatsii. Entomologicheskoe Obozrenie, 92:62-69. (Published in English as Gnezdilov, V.M. 2013.) "Issidisation" of fulgoroid planthoppers [Homoptera, Fulgoroidea] as a case of parallel adaptive radiation. Entomological Review, 93:825-830. https://doi.org/10.1134/S001387381307004X)

Gnezdilov, V.M. 2013b. Contribution to the taxonomy of the family Tropiduchidae Stål (Hemiptera, Fulgoroidea) with description of two new tribes from Afrotropical Region. Deutsche Entomologische Zeitschrift, 60:179-191. https://doi.org/10.1002/mmnd.201300024 
Gnezdilov, V.M., Bartlett, C.R., and Bourgoin, T. 2016. A new tribe of Tropiduchidae (Hemiptera: Fulgoroidea) with revision of the genus Buca and description of asymmetric hind leg spinulation. Florida Entomologist, 99:406-416.

Gnezdilov, V.M. and Bourgoin, T. 2015. New genera and new species of the tribe Elicini (Hemiptera: Fulgoroidea: Tropiduchidae) with key to tropiduchid genera known from Madagascar. Annales Zoologici, 65:599-618. https://doi.org/10.3161/ 00034541ANZ2015.65.4.007

Gnezdilov, V.M. and Bourgoin, T. 2016. On the taxonomic position of Issus reticulatus Bervoets, 1910 (Hemiptera: Fulgoroidea: Issidae) from Baltic amber. Entomological Review, 96:631633. https://doi.org/10.1134/S0013873816050092

Grimaldi, D.A., Shedrinsky, A., Ross, A., and Baer, N.S. 1994. Forgeries of fossils in "amber": history, identification and case studies. Curator, 37:251-274.

Junkiert, $Ł$. and Walczak, M. 2015. Three new species of the genus Exphora Signoret, 1860 (Hemiptera, Fulgoromorpha, Tropiduchidae) from Madagascar. Zootaxa, 3926:129-136. https://doi.org/10.11646/zootaxa.3926.1.7

Junkiert, Ł., Walczak, M., and Bourgoin, T. 2017. A new species of the genus Exphora Signoret, 1860 from Madagascar (Hemiptera: Auchenorrhyncha: Fulgoromorpha: Tropiduchidae). Entomologica Americana, 22:495-501.

Kerzhner, I.M. 1981. Poluzhestokrylye semeïstva Nabidae [Heteropterans of the family Nabidae]. Fauna SSSR. Nasekomye khobotnye [Fauna of the USSR. Insecta, Rhynchota], 13:1-326. (In Russian)

Kirkaldy, G.W. 1906. Leaf-hoppers and their natural enemies. (Pt. IX Leaf-hoppers. Hemiptera). Report of work of the Experiment Station of the Hawaiian Sugar Planters' Association. Division of Entomology Bulletin, 1:271-479.

Kirkaldy, G.W. 1907. Leafhoppers-Supplement. (Hemiptera). Bulletin of the Hawaiian Sugar Planters' Association Experimental Station Entomological Series, 3:1-186.

Kohlmann-Adamska, A. 2001. A graphic reconstruction of an "amber forest", p. 15-18. In Kosmowska-Ceranowicz, B. (ed.), The Amber Treasure Trove: The Tadeusz Giecewicz's Collection at the Museum of the Earth, Polish Academy of Sciences. Museum of the Earth Documentary Studies, 18. Oficyna Wydawnicza Sadyba, Warsaw.

Kosmowska-Ceranowicz, B. (ed.) 2015. Atlas. Infrared Spectra of the World's Resins. Holotype Characteristics. Museum of the Earth, Polish Academy of Sciences, Warsaw.

Kosmowska-Ceranowicz, B. 2017. Amber in Poland and in the World. Second Edition, Revised. Wydawnictwa Uniwersytetu Warszawskiego, Warsaw.

Liang, A.-P. and Wang, R.R. 2008a. First record of the genus Varma Distant, 1906 (Hemiptera: Fulgoroidea: Tropiduchidae) from China, with descriptions of two new species. Annales Zoologici, 58:115-123. https://doi.org/10.3161/000345408783897752

Liang, A.-P. and Wang, R.R. 2008b. A review of the Oriental planthopper genus Sogana Matsumura, 1914 (Hemiptera: Fulgoromorpha: Tropiduchidae) with descriptions of three new species. Zootaxa, 1732:29-44.

Linnaeus, C. 1758. Systema naturae per regna tria naturae, secundum classes, ordines, genera, species, cum characteribus, differentiis, synonymis, locis. Tomus I. Editio decima, reformata. Laurentii Salvii, Holmiæ.

Martínez-Delclòs, X., Briggs, D.E.G., and Peñalver, E. 2004. Taphonomy of insects in carbonates and amber. Palaeogeography, Palaeoclimatology, Palaeoecology, 203:19-64. https://doi.org/ 10.1016/S0031-0182(03)00643-6

Melichar, L. 1901. Monographie der Acanaloniiden und Flatiden (Homoptera). Annalen des k.k Naturhistorischen Hofmuseums, 16:178-258.

Melichar, L. 1914. Monographie der Tropiduchinen (Homoptera). Verhandlungen des Naturforschenden Vereins in Brünn, 53:1-145.

Melichar, L. 1915. Monographie der Lophopinen. Annales Historico-Naturales Musei Nationalis Hungarici, 13:337-385.

Naumann, I.D., Came, P.B., Lawrence, J.F., Nielsen, E.S., Spradbery, J.P., Taylor, R.W., Whitten, M.J., and Littlejohn, M.J. (eds.) 1991. The Insects of Australia: A Textbook for Students and Research Workers, 2nd Edition. Division of Entomology, CSIRO, Australia/Melbourne University Press, Melbourne/Cornell University Press, Ithaca, New York.

Nicholson, D.B., Mayhew, P.J., and Ross, A.J. 2015. Changes to the fossil record of insects through fifteen years of discovery. PLoS ONE, 10(7):e0128554. https://doi.org/10.1371/ journal.pone.0128554 
O'Brien, L.B. 2002. The wild wonderful world of Fulgoromorpha, p. 83-102. In Holzinger, W. (ed.), Zikaden-Leafhoppers, Planthoppers and Cicadas (Insecta: Hemiptera: Auchenorrhyncha). Denisia 4, Zugleich Kataloge, Neue Folge Nr. 176. OÖ, Landesmuseums, Linz.

O'Brien, L.B. and Wilson, S.W. 1985. Planthopper systematics and external morphology, p. 61101. In Nault, L.R. and Rodrigues, J.G. (eds.), The Leafhoppers and Planthoppers. Wiley, New York.

Perkovsky, E.E. 2016. Tropical and Holarctic ants in late Eocene ambers. Vestink Zoologii, 50:111-122. https://doi.org/10.1515/vzoo-2016-0014

Perkovsky, E.E., Zosimovich, V.Yu, and Vlaskin, A.P. 2010. Rovno Amber, p. 116-136. In Penney, D. (ed.), Biodiversity of Fossils in Amber from the Major World Deposits. Siri Scientific Press, Manchester.

Rascher, J., Wimmer, R., Krumbiegel, G., and Schmiedel, S. (eds.) 2008. Bitterfelder Bernstein versus Baltischer Bernstein: Hypothesen, Fakten, Fragen. II. Bitterfelder Bernsteinkolloquium. Exkursionsführer der Deutschen Gesellschaft für Geowissenchaften 236:1-166.

Sadowski, E.-M., Schmidt, A.R., Kunzmann, L. Gröhn, C., and Syfullah, L.J. 2016a. Sciadopitys cladodes from Eocene Baltic amber. Botanical Journal of the Linnean Society, 108:258-268. https://doi.org/10.111/boj.12365

Sadowski, E.-M., Schmidt, A.R., Rudall, P.J., Simpson, D.A., Gröhn, C., Wunderlich, J., and Seyfullah, L.J. 2016b. Graminids from Eocene Baltic amber. Review of Palaeobotany and Palynology, 233:161-168. https://doi.org/10.1016/j.revpalbo.2016.02.005

Schmidt, J., Hoffmann, H., and Michalik, P. 2016. Blind life in the Baltic amber forests: Description of an eyeless species of the ground beetle genus Trechus Clairville, 1806 (Coleoptera: Carabidae: Trechini). Zootaxa, 4083:431-443. https://doi.org/10.11646/ zootaxa.4083.3.7

Shcherbakov, D.E. 2006. The earliest find of Tropiduchidae (Homoptera: Auchenorrhyncha), representing a new tribe, from the Eocene of Green River, USA, with notes on the fossil record of higher Fulgoroidea. Russian Entomological Journal, 15:315-322.

Spinola, M. 1839. Essai sur les Fulgorelles, sous-tribu de la tribu des Cicadaires, ordre des Rhyngotes. (Suite). Annales de la Société Entomologique de France, 8:339-454.

Stål, C. 1854. Nya Hemiptera. Ofversigt af Kongliga Svenska Vetenskaps-Akademiens Förhandlingar, Stockholm, 11:231-255.

Stroiński A. and Gnezdilov, V.M. 2009. Redescription of Busas dissolutus Jacobi, 1909, with notes on taxonomic position of the genus (Hemiptera: Fulgoromorpha: Tropiduchidae). Annales Zoologici, 59:459-464. https://doi.org/10.3161/000345409X484856

Stroiński, A., Wang, R.R., Bourgoin, T., Liang, A.P., and Szwedo, J. 2015. Review of the Paricanini (Hemiptera: Fulgoromorpha: Tropiduchidae) - key to the genera and description of a new genus and species from Cambodia. Annales Zoologici, 65:579-597. https://doi.org/ 10.3161/00034541ANZ2015.65.4.006

Szwedo, J. 2000. First fossil Tropiduchidae with a description of a new tribe Jantaritambini from Eocene Baltic amber (Hemiptera: Fulgoroidea). Annales de la Société Entomologique de France (N.S.), 36:279-286.

Szwedo, J. 2002. Amber and amber inclusions of planthoppers, leafhoppers and their relatives (Hemiptera, Archaeorrhyncha et Clypaeorrhyncha), p. 37-56. In Holzinger, W. (ed.), ZikadenLeafhoppers, Planthoppers and Cicadas (Insecta: Hemiptera: Auchenorrhyncha). Denisia 4, Zugleich Kataloge, Neue Folge Nr. 176. OÖ, Landesmuseums, Linz.

Szwedo, J. 2009. First discovery of Neazoniidae (Hemiptera: Fulgoromorpha) in the Early Cretaceous Archingeay amber of South-West France. Geodiversitas, 31:105-116.

Szwedo, J. 2012. Life in the Eocene forests, p. 60-74. In Pytlos, R., Szadziewski, R., Zbierska, A., Adamska, G., and Dmowska, A. (eds.), World Amber Council Seminar. Gdańsk the World Amber Capital, Gdańsk, May 18-19, 2012. Mayor's Office for City Promotion, City Hall of Gdańsk, Gdańsk.

Szwedo, J. and Drohojowska, J. 2016. A swarm of whiteflies—the first record of gregarious behavior from Eocene Baltic amber. The Science of Nature, 103:35. https://doi.org/10.1007/ s00114-016-1359-y

Szwedo, J. and Kania, I. 2015. Climatic reconstructions based on inclusions, p. 6-21. In Pytlos, R., Szadziewski, R., Zbierska, A., Adamska, G., and Dmowska, A. (eds.), Amber News 
Review 2014/2015, World Amber Council, Gdańsk, Poland, 2015.Mayor's Office for City Promotion, City Hall of Gdańsk, Gdańsk.

Szwedo, J. and Sontag, E. 2009. The traps of the "amber trap". How inclusions could trap scientists with enigmas. Denisia, 26, zugleich Kataloge. oberösterreichischen Landesmuseen Neue Serie, 86:155-169.

Szwedo, J. and Stroiński, A. 1999. Redescription of Tritophania patruelis Jacobi, 1938 from Eocene Baltic amber (Hemiptera: Nogodinidae). Annales Zoologici, 49:203-207.

Szwedo, J. and Stroiński, A. 2010. Austrini - a new tribe of Tropiduchidae planthoppers from the Eocene Baltic amber (Hemiptera: Fulgoromorpha). Annales de la Société Entomologique de France, 46:132-137.

Szwedo, J. and Stroiński, A. 2013. An extraordinary tribe of Tropiduchidae from the Eocene Baltic amber, with notes on fossil taxa (Hemiptera: Fulgoromorpha: Fulgoroidea). Zootaxa, 3647:371-381. https://doi.org/10.11646/zootaxa.3647.2.8

Wang, M.L., Stroiński, A., Bourgoin, T., and Zhang, Y.L. 2015. A new Asian genus of the tribe Elicini (Hemiptera: Fulgoromorpha: Tropiduchidae) with two new species from Vietnam. Zootaxa, 4018:563-572. https://doi.org/10.11646/zootaxa.4018.4.5

Wang, R.R., Li, X.L., Szwedo, J., Stroiński, A., Liang, A.P., and Bourgoin, T. 2017. Testing Tropiduchini Stål 1866 (Hemiptera: Tropiduchidae) monophyly, a young inter-tropical taxon of mainly insular species: taxonomy, distribution patterns and phylogeny, with the description of a new genus from Papua New Guinea. Systematic Entomology, 42:359-378. https://doi.org/ 10.1111/syen.12219

Wang, R.R. and Liang, A.P. 2006. Descriptions of the female genitalia of Cixiopsis punctatus and Tambinia debilis (Hemiptera, Fulgoromorpha, Tropiduchidae). Acta Zootaxonomica Sinica, 31:509-512.

Wang, R.R. and Liang, A.P. 2007. Taxonomic study of the genus Zema Fennah (Hemiptera: Fulgoromorpha: Tropiduchidae) from China. Zootaxa, 1436:61-68.

Wang, R.R. and Liang, A.P. 2008. The genus Isporisa from China (Hemiptera, Fulgoroidea, Tropiduchidae) with description of a new species. Acta Zootaxonomica Sinica, 33:29-32.

Wang, R.R. and Liang, A.P. 2011. Taxonomic review of the genus Tambinia Stål (Hemiptera, Fulgoromorpha, Tropiduchidae) with descriptions of four new species from the Pacific region. ZooKeys, 132:13-31. https://doi.org/10.3897/zookeys.132.1571

Wang, R.R., Liang, A.P., and Webb, M.D. 2009. A new tropiduchid planthopper genus and species from China with descriptions of in copula genitalic structures (Hemiptera: Fulgoromorpha). Systematic Entomology, 34:434-442.

Wang, R.R., Malenovský, I., Liang, A.P., and Bourgoin, T. 2013a. Revision of Pseudoparicana (Hemiptera: Fulgoromorpha: Tropiduchidae) with description of a new species. European Journal of Entomology, 110:365-377.

Wang, R.R., Stroiński, A., Szwedo, J., Bourgoin, T., and Liang, A.P. 2014. Recent dispersal and diet relaxation might explain the monotypic and endemic genus Montrouzierana Signoret, 1861 in New Caledonia (Hemiptera: Fulgoromorpha: Tropiduchidae). Annales Zoologici, 64:693-708. https://doi.org/10.3161/000345414X685974

Wang, R.R., Wan, X.Y., Liang, A.P., and Bourgoin, T. 2012a. Ultrastructure of sensory equipments on the heads of Kallitaxila granulata (Stål) (Hemiptera: Fulgoromorpha: Tropiduchidae). Microscopy Research and Technique, 75:1659-1665. https://doi.org/ 10.1002/jemt.22113.

Wang, R.R., Wan, X.Y., Liang, A.P., and Bourgoin, T. 2013b. A SEM study of antennal and maxillary sensilla in Zema gressitti Fennah (Hemiptera: Fulgoromorpha: Tropiduchidae). Micron, 44:261-267. https://doi.org/10.1016/j.micron.2012.07.003

Wang, R.R., Webb, M.D., and Liang, A.P. 2010. First record of the male of Leusaba philippina Stål (Hemiptera: Fulgoromorpha: Tropiduchidae) with a redescription of the genus and species. Zootaxa, 2344:52-60.

Wang, R.R., Webb, M.D., and Liang, A.P. 2012b. Review of Lavora Muir (Hemiptera: Fulgoromorpha: Tropiduchidae) with descriptions of two new species from Solomon Islands. Insect Systematics \& Evolution, 43:299-319. https://doi.org/10.1163/1876312X-04303005

Wang, Y., Yang, M., and Yang, Y. 2014. Experimental studies on the heat treatment of Baltic amber. Gems \& Gemology, 50:142-150.

Wappler, T. 2003. Die Insekten aus dem Mittel-Eozän des Eckfelder Maares, Vulkaneifel. Mainzer Naturwissenschaftliches Archiv, 27:1-234. 
Wappler, T. 2005. The age of Baltic amber: Could Eckfeld resolve this problem?, p. 53. In Brothers, D. and Mostovski, M. (eds.), Fossils X3, 3rd International Congress of Palaeoentomology with $2^{\text {nd }}$ International Meeting on Palaeoarthropodology and $2^{\text {nd }}$ World Congress on Amber and its Inclusions. Programme and Abstracts, $7^{\text {th }}$ to $11^{\text {th }}$ Feb 2005, Pretoria South Africa. University of Kwazulu-Natal, South African National Biodiversity Institute, Pretoria.

Wilson, S.W., Mitter, C., Denno, R.F., and Wilson, M.R. 1994. Evolutionary patterns of host plant use by delphacid planthoppers and their relatives, p. 7-113. In Denno, R.F. and Perfect, T.J. (eds.), Planthoppers: Their Ecology and Management. Chapman \& Hall, New York.

Wolfe, A.P., McKellar, R.C., Tappert, R., Sodhi, R.N.S., and Muehlenbachs, K. 2016. Bitterfeld amber is not Baltic amber: three geochemical tests and further constraints on the botanical affinities of succinite. Review of Palynology and Palaeobotany, 225:21-32. https://doi.org/ 10.1016/j.revpalbo.2015.11.002

Wolfe, A.P., Tappert, R., Muehlenbachs, K., Boudreau, M., McKellar, R.C., Basinger, J.F., and Garrett, A. 2009. A new proposal concerning the botanical origin of Baltic amber. Proceedings of the Royal Society B, 276:3403-3412. https://doi.org/10.1098/rspb.2009.0806 Zherikhin, V.V. 1980. Nasekomye $v$ ekosistemakh sushi [Insects in terrestrial ecosystems], p. 189-224. In Rohdendorf, B.B. (ed.), Istoricheskoe razvite klassa nasekomykh [Historical Development of Class Insecta]. Trudy Paleontologicheskogo Instituta Akademii Nauk SSSR, 175. Nauka, Moscow. (in Russian)

Zherikhin, V.V. 2002. Pattern of insect burial and conservation, p. 17-62. In Rasnitsyn, A.P. and Quicke, D.L.J. (eds.), History of Insects. Kluwer Academic Publishers, Dordrecht. 


\section{APPENDIX 1.}

Classification systems of Tropiduchidae.

\begin{tabular}{|c|c|c|c|c|c|}
\hline \multicolumn{2}{|c|}{ Fennah (1982) } & \multirow{2}{*}{$\begin{array}{l}\text { Additions and } \\
\text { changes as of } \\
2013\end{array}$} & \multicolumn{3}{|c|}{ Gnezdilov (2013b) and this study } \\
\hline Tribe & Subtribe & & Subfamily & Tribe & Subtribe \\
\hline $\begin{array}{l}\text { Alcestini Melichar, } \\
1914\end{array}$ & & & $\begin{array}{l}\text { Tropiduchinae } \\
\text { Stål, } 1866\end{array}$ & $\begin{array}{l}\text { Alcestini Melichar, } \\
1914\end{array}$ & \\
\hline \multirow[t]{2}{*}{$\begin{array}{l}\text { Catullini Melichar, } \\
1914\end{array}$} & & & & $\begin{array}{l}\text { Catullini Melichar, } \\
1914\end{array}$ & \\
\hline & & & & $\begin{array}{l}\text { Chrysopuchini } \\
\text { Gnezdilov, } 2013\end{array}$ & \\
\hline $\begin{array}{l}\text { Cixiopsini Fennah, } \\
1982\end{array}$ & & & & $\begin{array}{l}\text { Cixiopsini Fennah, } \\
1982\end{array}$ & \\
\hline $\begin{array}{l}\text { Cyphoceratopini } \\
\text { Fennah, } 1945\end{array}$ & & & & $\begin{array}{l}\text { Cyphoceratopini } \\
\text { Fennah, } 1945\end{array}$ & \\
\hline \multirow[t]{2}{*}{$\begin{array}{l}\text { Eporini Fennah, } \\
1982\end{array}$} & $\begin{array}{l}\text { Eporina } \\
\text { Fennah, } 1982\end{array}$ & & & $\begin{array}{l}\text { Eporini Fennah, } \\
1982\end{array}$ & $\begin{array}{l}\text { Eporina Fennah, } \\
1982\end{array}$ \\
\hline & $\begin{array}{l}\text { Clardeina } \\
\text { Fennah, } 1982\end{array}$ & & & & $\begin{array}{l}\text { Clardeina Fennah, } \\
1982\end{array}$ \\
\hline \multirow[t]{3}{*}{$\begin{array}{l}\text { Eutropistini Kirkaldy, } \\
1906\end{array}$} & $\begin{array}{l}\text { Duriina Fennah, } \\
1982\end{array}$ & & & $\begin{array}{l}\text { Eutropistini } \\
\text { Kirkaldy, } 1906\end{array}$ & $\begin{array}{l}\text { Duriina Fennah, } \\
1982\end{array}$ \\
\hline & $\begin{array}{l}\text { Eutropistina } \\
\text { Fennah, } 1982\end{array}$ & & & & $\begin{array}{l}\text { Eutropistina Fennah, } \\
1982\end{array}$ \\
\hline & $\begin{array}{l}\text { Kazerunina } \\
\text { Dlabola, } 1977\end{array}$ & & & & $\begin{array}{l}\text { Kazerunina Dlabola, } \\
1977\end{array}$ \\
\hline $\begin{array}{l}\text { Isporisini Fennah, } \\
1982\end{array}$ & & & & $\begin{array}{l}\text { Isporisini Fennah, } \\
1982\end{array}$ & \\
\hline $\begin{array}{l}\text { Neomatissini, } \\
\text { Fennah } 1982\end{array}$ & & & & $\begin{array}{l}\text { Neomatissini, } \\
\text { Fennah, } 1982\end{array}$ & \\
\hline $\begin{array}{l}\text { Paricanini Melichar } \\
1914\end{array}$ & & & & $\begin{array}{l}\text { Paricanini Melichar, } \\
1914\end{array}$ & \\
\hline $\begin{array}{l}\text { Tambiniini Kirkaldy, } \\
1907\end{array}$ & & & & $\begin{array}{l}\text { Tambiniini Kirkaldy, } \\
1907\end{array}$ & \\
\hline \multirow[t]{3}{*}{$\begin{array}{l}\text { Tangiini Melichar, } \\
1914\end{array}$} & $\begin{array}{l}\text { Tangiina } \\
\text { Fennah, } 1982\end{array}$ & & & $\begin{array}{l}\text { Tangiini Melichar, } \\
1914\end{array}$ & $\begin{array}{l}\text { Tangiina Fennah, } \\
1982\end{array}$ \\
\hline & $\begin{array}{l}\text { Neotangiina } \\
\text { Fennah, } 1982\end{array}$ & & & & $\begin{array}{l}\text { Neotangiina Fennah, } \\
1982\end{array}$ \\
\hline & & $\begin{array}{l}\text { Trienopini } \\
\text { Fennah, } 19541\end{array}$ & & $\begin{array}{l}\text { Trienopini Fennah, } \\
1954\end{array}$ & \\
\hline $\begin{array}{l}\text { Trypetimorphini } \\
\text { Melichar, } 1914\end{array}$ & & & & $\begin{array}{l}\text { Trypetimorphini } \\
\text { Melichar, } 1914\end{array}$ & \\
\hline $\begin{array}{l}\text { Turneriolini Fennah, } \\
1982\end{array}$ & & & & $\begin{array}{l}\text { Turneriolini Fennah } \\
1982\end{array}$ & \\
\hline \multirow[t]{4}{*}{$\begin{array}{l}\text { Tropiduchini } \\
\text { Melichar, } 1914\end{array}$} & & & & $\begin{array}{l}\text { Tropiduchini } \\
\text { Melichar, } 1914\end{array}$ & \\
\hline & & $\begin{array}{l}\text { †Jantaritambini } \\
\text { Szwedo, } 2000\end{array}$ & & $\begin{array}{l}\text { †Jantaritambini } \\
\text { Szwedo, } 2000^{2}\end{array}$ & \\
\hline & & $\begin{array}{l}\text { †Emilianini } \\
\text { Shcherbakov, } \\
2007\end{array}$ & & $\begin{array}{l}\text { †Emilianini } \\
\text { Shcherbakov, } \\
2007^{3}\end{array}$ & \\
\hline & & $\begin{array}{l}\text { Gaetuliini } \\
\text { Fennah, } 1978^{4}\end{array}$ & $\begin{array}{l}\text { Elicinae Melichar, } \\
1915\end{array}$ & $\begin{array}{l}\text { Elicini Melichar, } \\
1915\end{array}$ & \\
\hline
\end{tabular}




\begin{tabular}{|c|c|c|c|c|c|}
\hline \multicolumn{2}{|c|}{ Fennah (1982) } & \multirow{2}{*}{$\begin{array}{l}\text { Additions and } \\
\text { changes as of } \\
2013\end{array}$} & \multicolumn{3}{|c|}{ Gnezdilov (2013b) and this study } \\
\hline Tribe & Subtribe & & Subfamily & Tribe & Subtribe \\
\hline & & & & $\begin{array}{l}\text { Parathiscini } \\
\text { Gnezdilov, } 2013\end{array}$ & \\
\hline & & & & $\begin{array}{l}\text { Bucini Gnezdilov, } \\
\text { Bartlett and } \\
\text { Bourgoin, } 2016\end{array}$ & \\
\hline & & $\begin{array}{l}\text { †Austrini } \\
\text { Szwedo and } \\
\text { Stroiński, } 2010\end{array}$ & & $\begin{array}{l}\text { †Austrini Szwedo } \\
\text { and Stroiński, } \\
2010^{5}\end{array}$ & \\
\hline & & $\begin{array}{l}\text { †Patollini } \\
\text { Szwedo and } \\
\text { Stroiński, } 2013\end{array}$ & & $\begin{array}{l}\text { †Patollini Szwedo } \\
\text { and Stroiński, } \\
2013^{6}\end{array}$ & \\
\hline & & & & $\begin{array}{l}\text { Gedanotropidini } \\
\text { trib. nov. }\end{array}$ & \\
\hline
\end{tabular}

1 Transferred from Issidae by Gnezdilov (2007).

2 Described from Eocene Baltic amber. Provisionally placed in Tropiduchinae by Gnezdilov (2013b).

3 Described from Eocene imprint of Green River Formation, Colorado, U.S.A. Provisionally placed in Tropiduchinae by Gnezdilov (2013b).

4 The taxon was established as subtribe Gaetuliina Fennah, 1978 in the tribe Bladinini of the family Nogodinidae. Gnezdilov (2007) transferred it as tribe, to Tropiduchidae. Gnezdilov (2013b) synonymized Gaetuliina under Elicini Melichar, 1915. Provisionally placed in Elicinae by Gnezdliov (2013b).

5 Described from Eocene Baltic amber. Provisionally placed in Elicinae by Gnezdliov (2013b).

6 Described from Eocene Baltic amber. Provisionally placed in Elicinae by Gnezdliov (2013b). 


\section{APPENDIX 2.}

Key to identification of Tropiduchidae genera from Baltic amber.

1. Tegmina macropterous -

- Tegmina brachypterous - - $-1, \ldots$

2. Costal area absent; stems $\mathrm{ScP}+\mathrm{R}, \mathrm{MP}$ and CuA leaving basal cell separately, forked distinctly basad of half of tegmen length

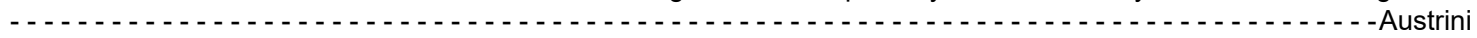
genus Austris Szwedo and Stroiński, 2010

- Costal area present, not reaching to apex of clavus; stems ScP+R and MP leaving basal cell with short common stalk;

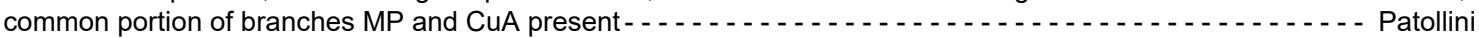
genus Patollo Szwedo and Stroiński, 2013

3. Venation not reticulate, wide costal area absent, head with compound eyes narrower than pronotum

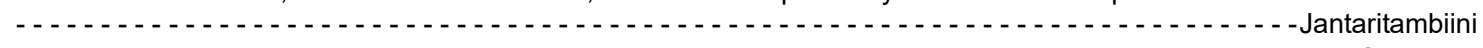
genus Jantaritambia Szwedo, 2000

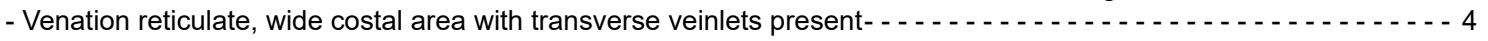

4. Head with compound eyes wider than pronotum; tegmen venation forming regular polygonal cells; gonoplac with teeth - . genus Tritophania Jacobi, 1938

- Head with compound eyes narrower than pronotum; tegmen with transverse veinlets forming irregular network; gonoplac without teeth genus Gedanotropis gen. nov. 